\title{
Effects of Cold Water Swimming on Blood Rheological Properties and Composition of Fatty Acids in Erythrocyte Membranes of Untrained Older Rats
}

\author{
Aneta TelegŁów, Zbigniew DĄBrowsKi, Anna MARChEwKA, Zbigniew TABAROwSKI, \\ Jan BILSKI, Jerzy JAŚKIEWICZ, Joanna GDULA-ARGASIŃSKA, Jacek GŁODZIK, Dorota LIZAK, \\ and Magdalena KĘPIŃSKA
}

Accepted May 19, 2011

\begin{abstract}
TelegŁów A., DĄBrowski Z., Marchewka A., TABArowski Z., Bilski J., JaŚkiewicZ J., GDUlA-ARGASIŃSKA J., GŁODZIK J. LiZAK D., KĘPIŃSKA M. 2011. Effects of cold water swimming on blood rheological properties and composition of fatty acids in erythrocyte membranes of untrained older rats. Folia biologica (Kraków) 59: 203-209.

This is the first report on the effects of a single bout of swimming to exhaustion in cold water on rat erythrocyte deformability, aggregation and fatty acid composition in erythrocyte membranes. The results indicate that there was a significant decrease in body temperature of experimental rats swimming in water at $4^{\circ} \mathrm{C}$ and $25^{\circ} \mathrm{C}$ when compared to the control. Erythrocyte aggregation indices did not change after swimming in water at $4^{\circ} \mathrm{C}$ whereas erythrocyte deformability increased at shear stress $1,13[\mathrm{~Pa}]$ and 15,96 [Pa]. Physical effort performed in water at $4{ }^{\circ} \mathrm{C}$ when compared to the control group resulted in an increase in monounsaturated and polyunsaturated n-3 fatty acid content in erythrocyte membranes that influenced the increase in their fluidity and permeability even though that of polyunsaturated $\mathrm{n}-6$ fatty acids decreased.Physical effort performed in $25^{\circ} \mathrm{C}$ water resulted in an increase in saturated fatty acid content and a decrease in all polyunsaturated fatty acids and polyunsaturated n-6 fatty acids when compared to the control group. Swimming of untrained old rats in cold water affected rheological properties of erythrocytes in a negligible way while changes in the fatty acid composition of erythrocyte membranes were more pronounced.

Key words: Swimming rats, blood rheology, fatty acid composition of erythrocyte membranes.

Aneta TELEGEÓW, Zbigniew DARBROWSKI, Anna MARCHEWKA, Department of Clinical Rehabilitation, University School of Physical Education, Jana PawłaII 78, 31-571 Kraków, Poland. E-mail: aneta.teleglow@awf.krakow.pl

Zbigniew TABAROWSKI, Department of Animal Physiology, Institute of Zoology, Jagiellonian University, Ingardena 6, 30-060 Kraków, Poland

Jan BILSKI, Department of Ergonomics and Exercise Physiology, Faculty of Health Sciences, Jagiellonian University Medical College, Grzegórzecka 20, 31-531 Kraków, Poland

Jerzy JAŚKIEWICZ, Joanna GDULA-ARGASIŃSKA, Department of Analytical Biochemistry, Jagiellonian University Medical College, Medyczna 9, 30-688 Kraków, Poland.

Jacek GEODZIK, Department of Physiotherapy, University School of Physical Education Jana Pawta II 78, 31-571 Kraków, Poland.

Dorota LIZAK, Department of Health and Medical Sciences, Andrzej Frycz Modrzewski Cracow University, Gustawa Herlinga Grudzińskiego 1, 30-705 Kraków, Poland.

Magdalena KE PIŃSKA, Doctoral student, University School of Physical Education, Jana Pawła II 78, 31-571 Kraków, Poland.
\end{abstract}

Red blood cell deformability is the ability of these cells to change their shape under forces encountered during circulation. Deformation of red cells is an essential quality necessary for normal circulation. The erythrocyte membrane is formed by a lipid bilayer (SHIGA et al. 1990). Alterations in the transbilayer distribution of phospholipids in the erythrocyte membrane have significant physiologic consequences such as changes in erythrocyte shape leading to disturbed elasticity. Red blood cells of the rat, $5-7 \mu \mathrm{m}$ in diameter, possess the ability to alter their shape in order to squeeze through capillaries of even smaller diameter. Deformability has an important effect on microcirculation and depends on three parameters: 1. membrane deformability and stability, which are regulated by multiple membrane properties including elastic shear modulus, bending modulus, and yield stress. 2. cell shape or cell geometry determining the ratio of cell surface area to cell volume (SA/V); higher values of SA/V facilitate deformation. 3. cytoplasmic viscosity, which is primarily regulated 
by the mean corpuscular hemoglobin concentration (MCHC) and is therefore influenced by alterations in cell volume (MOKKEN et al. 1992). Increased red cell deformability may result from incorporation of polyunsaturated fatty acids (PUFA n-3) from blood plasma into erythrocyte membranes (OOSTENBURG et al. 1997). It was found that fish oil ingested as a dietary supplement can induce an increase in PUFA n-3 fatty acid content in the erythrocyte membrane ameliorating membrane fluidity which favors erythrocyte deformability (KAMADA et al. 1993). Proper blood liquidity depends on the level of unsaturated fatty acids (UNSAT) in erythrocyte membranes and saturated ones (SAT), being the sum of various unsaturated and saturated fatty acids respectively. DODGE et al. (1967) and CRIBIER et al. (1993) show that higher UNSAT content increases membrane liquidity since they have substantially lower melting points than their saturated counterparts. The increase in unsaturated acid contents in erythrocyte membranes facilitates the transport of water molecules through the membrane, equalizing intracellular pressure and osmotic balance (PLASENZOTTI et al. 2007). The fluidity is low if the membrane is in a gel state at low temperature and it is high when temperature increases (ISLAM et al. 2011). Lower erythrocyte deformability increases blood viscosity resulting in disturbances in blood flow within the microcirculation. Blood viscosity is influenced by plasma protein level and RBC and WBC numbers (DABBROWSKI 2000; MCHEDLISHVILI et al. 2001). This dependence was confirmed by EL-SAYED et al. (2005) who indicated that an increase in the whole blood viscosity is seen with an increase in hematocrit and plasma viscosity without accompanying changes in erythrocyte deformability and aggregation. Interestingly WEN et al. (1995) demonstrated that the increase in viscosity observed at lower temperatures could influence erythrocyte elongation.

The objective of our study was to subject rats to a single bout of intensive physical effort in water at $4^{\circ} \mathrm{C}$ and $25^{\circ} \mathrm{C}$ and to study its impact on the rheological properties of blood erythrocytes (EI, AI, blood plasma viscosity) and the composition of fatty acids in the erythrocyte membranes (percentage content of unsaturated, saturated, monounsaturated, and polyunsaturated fatty acids).

\section{Material and Methods}

\section{Animals}

Permission for this study was obtained from the Local Ethics Committee of the Jagiellonian Universitynumber ZI/UJ/96/2001.
Thirty 36-week old Wistar male rats were used in the experiment and randomly allocated to three research groups: 1) non-swimming controls kept in cages at room temperature, 2) rats swimming in water at $4^{\circ} \mathrm{C}$, and 3 ) rats swimming in water at $25^{\circ} \mathrm{C}$. Prior to the commencement of the experiment, a number of preliminary trials were carried out in order to determine the right duration of time for swimming at $4{ }^{\circ} \mathrm{C}$ and $25^{\circ} \mathrm{C}$, and to observe at what point the animals gave up further swimming. The experiments were performed during morning hours, i.e. between 9 AM and 12.00 PM. Animals swam in a glass container $(120 \mathrm{~cm}$ in length, $40 \mathrm{~cm}$ in width, and $50 \mathrm{~cm}$ in depth). The temperature of the water was adjusted with the aid of a PT-217 thermometer (Elmetron). At the end of the exercise session, the rectal temperature of all participating rats was taken. After completion of the experiment, the animals were killed by cervical dislocation. The femoral artery and vein were cut open and $6 \mathrm{ml}$ of blood was extracted and placed in Vacuette-type test tubes with potassium EDTA.

\section{Rheological analysis}

The deformability and aggregation of red blood cells was determined using a Laser-assisted Optical Rotational Cell Analyzer (LORRCA, RR Mechatronics, Holland) according to Hardeman's method (HARDEMAN et al. 1994; HARDEMAN et al. 2001). The deformability was expressed using EI. The following aggregation parameters were estimated: 1) $\mathrm{AI}($ in \%), 2) the amplitude and total extent of aggregation (AMP, in arbitrary units), and 3 ) the half time $\left(\mathrm{T}^{1} / 2\right.$, in $\left.\mathrm{s}\right)$ which describes the kinetics of the aggregation process and is proportional to the time of re-aggregation of disintegrated red cell complexes. Measurements of aggregation parameters were carried out at native hematocrit. The temperature in the LORCA was adjusted to $37^{\circ} \mathrm{C}$. All other preparations and measurements were carried out at room temperature $\left(22 \pm 1^{\circ} \mathrm{C}\right)$. For each measurement of deformability, we needed only $25 \mu$ of blood in $5 \mathrm{ml}$ of $0.14 \mathrm{mM}$ polivinylopyrrolidone (PVP, $\mathrm{M}=360$ 000) solution. A sample of diluted blood was injected into the LORCA measuring system. The samples were subjected to varying levels of shear stress. This process was fully automated (a shear stress of between $0.30 \mathrm{~Pa}$ and 59.97 $\mathrm{Pa}$ was used). The EI for erythrocytes was calculated according to the formula:

$$
\mathrm{EI}=(\mathrm{A}-\mathrm{B}) /(\mathrm{A}+\mathrm{B})
$$

where $\mathrm{A}$ and $\mathrm{B}$ represent the vertical and horizontal axes of the ellipsoid, respectively. EI allowed for the estimation of erythrocyte elasticity and was calculated based on the change in erythrocyte shape (from round to ellipsoid) under the influence of shear stress. 
Aggregation measurements obtained from the LORCA aggregometer were based on the detection of laser light back-scattering from the sheared (disaggregated) and unsheared (aggregating) blood using a computer assisted system. Each $2 \mathrm{ml}$ sample of blood was transferred into a glass vessel and oxygenated for 10 to 15 minutes prior to obtaining measurements. A $1 \mathrm{ml}$ sample of blood was injected into the gap between the outer cylinder "cup" and inner cylinder "bob" of the LORCA. During the measurement, the cup was driven by a computer-controlled stepper motor. The blood sample was sheared at $400 \mathrm{~s}^{-1}$, when shear rate decreases rapidly to zero. The backscattering data was evaluated by the computer and the AI was calculated from the syllectrogram (light scatter vs. time curve during a $120 \mathrm{~s}$ period). This method relies on the fact that there is less light backscattered from aggregating red cells.

\section{Measurements of blood plasma viscosity}

The viscosity of blood plasma was determined in a viscosimeter (type D-52159 Roetgen, Myrenne, Germany) with results displayed in $\mathrm{mPa}$.s.

\section{Biochemical analyses}

Isolation of cell membranes from the rat erythrocytes

The isolation of cell membranes followed the method proposed by RODRIGUEZ et al. (1996).

\section{Total lipid extraction}

Total lipid extraction from the erythrocyte membranes was carried out according to the method proposed by FOLCH et al. (1957).

Synthesis of fatty acid methyl esters of total lipids in the erythrocyte membranes

The synthesis of fatty acid methyl esters of total lipids in the erythrocyte membranes was carried out following the method developed by METCALFE and SCHMITZ (1961).
Separation of fatty acid methyl esters of total lipids extracted from erythrocyte membranes

The separation of fatty acid methyl esters of total lipids isolated from the red blood cells was carried out using the method of capillary chromatographic gas extraction according to LI and WATKINS (1998).

\section{Statistics}

Continuous variables were presented as arithmetic means along with their standard deviations, ranges. The normality of distribution was tested using the Shapiro-Wilk test. Arithmetic means between groups of rats subjected to exercise at $4^{\circ} \mathrm{C}$ or $25^{\circ} \mathrm{C}$ and the controls were analysed for statistical significance. The comparison of mean values of data that conformed to a normal distribution was carried out using one-way analysis of variance. When differences were found to be statistically important the post-hoc Tukey test was applied. In case of data that did not follow a normal distribution a nonparametric analysis of variance (ANOVA) with Kruskal-Wallis test was used. Calculations were performed using Statistica $7\left(\right.$ StatSoft $^{\circledR}$, Poland) software, and statistical significance was defined as $\mathrm{P} \leq 0.05$.

\section{Results}

\section{Animals}

Table 1 shows data characterizing rats from both experimental groups and those serving as a control.

\section{Post exercise body (rectal) temperature}

The values of post-exercise body (rectal) temperature decreased by $12.84^{\circ} \mathrm{C}$ in 36 -week old rats swimming in water at $4^{\circ} \mathrm{C}$ compared to the control group. Likewise, this value decreased by $11.91{ }^{\circ} \mathrm{C}$ in the group swimming in water at $25^{\circ} \mathrm{C}$ compared to the control group.

Table 1

Description of experimental animals and conditions

\begin{tabular}{|l|c|c|c|c|c|c|}
\hline Group & Age (weeks) & $\begin{array}{c}\text { Not swimming } \\
\text { (control) }\end{array}$ & $\begin{array}{c}\text { Swimming at } 4^{\circ} \mathrm{C} \\
(\mathrm{min}, \mathrm{mean} \pm \mathrm{SD})\end{array}$ & $\begin{array}{c}\text { Swimming at } \\
25^{\circ} \mathrm{C}(\mathrm{min})\end{array}$ & $\mathrm{n}$ & Weight (g) \\
\hline I & 36 & yes & - & - & 10 & $529.0 \pm 10.7$ \\
\hline II & 36 & - & $4.92 \pm 0.45$ & - & 10 & $527.8 \pm 19.98$ \\
\hline III & 36 & - & - & 60 & 10 & $530.8 \pm 13.68$ \\
\hline
\end{tabular}


Table 2

Mean values $( \pm \mathrm{SD})$ of rectal rtemperature in rats swimming in water at $4^{\circ} \mathrm{C}$ or $25^{\circ} \mathrm{C}$ and control ones

\begin{tabular}{|l|c|c|c|}
\hline & Control & Swimming at $4^{\circ} \mathrm{C}$ & Swimming at $25^{\circ} \mathrm{C}$ \\
\hline Rectal temperature $\left({ }^{\circ} \mathrm{C}\right)$ & $35.66 \pm 1.52$ & $22.82 \pm 1.56^{*}$ & $23.75 \pm 0.8^{*}$ \\
\hline
\end{tabular}

*significantly different when compared to controls $(\mathrm{P}<0.05)$

Table 3

Mean values $( \pm \mathrm{SD})$ of the elongation index at various levels of shear stress in rats swimming in water at $4^{\circ} \mathrm{C}$ or $25^{\circ} \mathrm{C}$ and control ones

\begin{tabular}{|c|c|c|c||}
\hline Shear stress $(\mathrm{Pa})$ & Control & Swimming at $4^{\circ} \mathrm{C}$ & Swimming at $25^{\circ} \mathrm{C}$ \\
\hline \hline 0.30 & $0.055 \pm 0.004$ & $0.06 \pm 0.02$ & $0.064 \pm 0.01$ \\
\hline 0.58 & $0.1 \pm 0.009$ & $0.12 \pm 0.02$ & $0.11 \pm 0.01$ \\
\hline 1.13 & $0.19 \pm 0.006$ & $0.22 \pm 0.022^{*}$ & $0.21 \pm 0.02$ \\
\hline 2.19 & $0.31 \pm 0.007$ & $0.33 \pm 0.02$ & $0.32 \pm 0.03$ \\
\hline 4.24 & $0.41 \pm 0.01$ & $0.42 \pm 0.03$ & $0.41 \pm 0.03$ \\
\hline 8.23 & $0.46 \pm 0.025$ & $0.48 \pm 0.04$ & $0.46 \pm 0.02$ \\
\hline 15.96 & $0.49 \pm 0.023$ & $0.51 \pm 0.04^{*}$ & $0.5 \pm 0.02^{* * *}$ \\
\hline 31.04 & $0.53 \pm 0.029$ & $0.55 \pm 0.05$ & $0.54 \pm 0.03$ \\
\hline 59.97 & $0.56 \pm 0.029$ & $0.57 \pm 0.06$ & $0.56 \pm 0.03$ \\
\hline
\end{tabular}

* significantly different when compared to control $(\mathrm{P}<0.05)$

$* *$ - statistically significant between groups at $4^{\circ} \mathrm{C}$ and $25^{\circ} \mathrm{C}$.

\section{Elongation index}

In post-hoc tests, the mean level of EI at a shear stress level of 1.13 was significantly higher in rats swimming in water at $4^{\circ} \mathrm{C}$ compared with the control group (Table 1). In post-hoc tests, the mean value of EI at shear stress 15.96 was significantly higher in rats swimming in water at $4^{\circ} \mathrm{C}$ and also at $25^{\circ} \mathrm{C}$ compared with the control group.

\section{Aggregation indices and blood plasma viscosity}

In post-hoc tests, the mean blood plasma viscosity was significantly higher in rats swimming in water at $4^{\circ} \mathrm{C}$ compared with the control group.

\section{Biochemical analyses}

Our study revealed the presence of the same fatty acids in the erythrocyte membranes of the control group as in the groups of rats swimming in water at $4^{\circ} \mathrm{C}$ and at $25^{\circ} \mathrm{C}$. The following fatty acids were found in all three groups: caprilic, capric, lauric, myristic, myristoleic, palmitic, palmitoleic, stearic, oleic, elaidinic, linoleic, $\alpha$-linoleic, arachidic, cis11-eicozenoic, behenic, erucic, and adrenic acids.
The consulted reference values for fatty acids found in the membranes of erythrocytes are in the form of indices, e.g. saturated (SAT), unsaturated (UNSAT), saturated/unsaturated (SAT/UNSAT), monounsaturated (MUFA), polyunsaturated (PUFA), polyunsaturated $n-3(\Sigma \mathrm{n} 3)$, and polyunsaturated n-6 ( $\Sigma \mathrm{n} 6)$.

In post-hoc tests, the mean SAT content was significantly higher in rats swimming in water at $25^{\circ} \mathrm{C}$ when compared to the control group (Table 6).

In post-hoc tests, the mean content of MUFA was significantly higher in rats swimming in water at $4{ }^{\circ} \mathrm{C}$ when compared to the control group and in rats swimming in water at $25^{\circ} \mathrm{C}$ when compared to the control group.

In post-hoc tests, the mean content of PUFA was significantly lower in rats swimming in water at $25^{\circ} \mathrm{C}$ when compared to the control group. For rats swimming in water at $4^{\circ} \mathrm{C}$ the difference was just below statistical significance due to the high dispersion of data.

In post-hoc tests, the mean content of $\Sigma \mathrm{n} 3$ was significantly higher in rats swimming in water at $4^{\circ} \mathrm{C}$ compared to the control group. This was not the case for rats swimming in water at $25^{\circ} \mathrm{C}$. 
Table 4

Mean values $( \pm \mathrm{SD})$ of the aggregation index $(\mathrm{AI})$, half-time of total aggregation $\left(\mathrm{T}^{1} / 2\right)$, of the total extent of aggregation (AMP) and blood plasma viscosity (BPV) in rats swimming in water at $4^{\circ} \mathrm{C}$ or $25^{\circ} \mathrm{C}$ and in control

\begin{tabular}{|l|c|c|c|}
\hline \multicolumn{1}{|c|}{ Parameter } & Controls & Swimming at $4^{\circ} \mathrm{C}$ & Swimming at $25^{\circ} \mathrm{C}$ \\
\hline AI (\%) & $59.5 \pm 7.75$ & $75.06 \pm 4.82$ & $72.21 \pm 12.3$ \\
\hline $\mathrm{T}^{\prime \prime}(\mathrm{s})$ & $1.69 \pm 0.1$ & $0.98 \pm 0.33$ & $1.37 \pm 0.82$ \\
\hline AMP (au) & $3.75 \pm 6.18$ & $12.94 \pm 3.42$ & $12.98 \pm 5.22$ \\
\hline BPV (mPa.s.) & $1.25 \pm 0.02$ & $1.49 \pm 0.06^{*}$ & $1.35 \pm 0.13$ \\
\hline
\end{tabular}

* significantly different when compared to controls $(\mathrm{P}<0.05)$

Table 5

Fatty acids present in erythrocyte membranes of experimental rats

\begin{tabular}{|c|c|c|c|c|c|c|}
\hline Fatty acid & SAT & UNSAT & MUFA & PUFA & \multicolumn{2}{|c|}{ n-3 PUFAsn-6 PUFAs } \\
\hline caprilic (C8:0) & $\mathrm{X}$ & & & & & \\
\hline capric (C10:0) & $\mathrm{X}$ & & & & & \\
\hline lauric (C12:0) & $\mathrm{X}$ & & & & & \\
\hline myristic (C14:0) & $\mathrm{X}$ & & & & & \\
\hline myristoleic (C14:1n-9) & & $\mathrm{X}$ & $\mathrm{X}$ & & & \\
\hline palmitic (C16:0) & $\mathrm{X}$ & & & & & \\
\hline palmitoleic (C16:1n-9) & & & $\mathrm{X}$ & & & \\
\hline stearic (C18:0) & $\mathrm{X}$ & & & & & \\
\hline oleic (C18:1n-9) & & $\mathrm{X}$ & $\mathrm{X}$ & & & \\
\hline elaidinic (C18:1n-9trans) & & $\mathrm{X}$ & $\mathrm{X}$ & & & \\
\hline linoleic (C18:2n-6) & & $\mathrm{X}$ & & $\mathrm{X}$ & & $\mathrm{X}$ \\
\hline$\alpha$-linoleic (C18:3n-3) & & $\mathrm{X}$ & & $\mathrm{X}$ & $\mathrm{X}$ & \\
\hline arachidic $(\mathrm{C} 20: 0)$ & $\mathrm{X}$ & & & & & \\
\hline cis-11-eicosenoic (C20:1) & & $\mathrm{X}$ & $\mathrm{X}$ & & & \\
\hline behenic $(\mathrm{C} 22: 0)$ & $\mathrm{X}$ & & & & & \\
\hline erucic (C22:1n-9) & & $\mathrm{X}$ & $\mathrm{X}$ & & & \\
\hline adrenic (C22:4n-6) & & $\mathrm{X}$ & & $\mathrm{X}$ & & $\mathrm{X}$ \\
\hline
\end{tabular}

Table 6

Mean content $( \pm \mathrm{SD})$ of saturated (SAT), unsaturated (UNSAT), saturated/unsaturated (SAT/UNSAT), fatty monounsaturated (MUFA), polyunsaturated (PUFA), n-3 polyunsaturated (n-3 PUFAS) and n-6 polyunsaturated (n-6 PUFAs) fatty acids in the erythrocyte membranes of rats swimming in water at $4^{\circ} \mathrm{C}$ or $25^{\circ} \mathrm{C}$ and in control ones calculated based on percentage content of various fatty acids in the lipids forming erythrocyte membrane

\begin{tabular}{|l|c|c|c|}
\hline \multicolumn{1}{|c|}{ Fatty acids } & Control & Swimming at $4^{\circ} \mathrm{C}$ & Swimming at $25^{\circ} \mathrm{C}$ \\
\hline SAT & $54.06 \pm 12.93$ & $66.78 \pm 4.94$ & $70.55 \pm 3.62^{*}$ \\
\hline UNSAT & $40.88 \pm 13.25$ & $34.57 \pm 6.42$ & $31.56 \pm 5.72$ \\
\hline SAT/UNSAT & $1.49 \pm 0.74$ & $2.01 \pm 0.53$ & $2.31 \pm 0.54$ \\
\hline MUFA & $11.34 \pm 5.7$ & $22.22 \pm 4.79^{*}$ & $20.51 \pm 1.96^{*}$ \\
\hline PUFA & $31.63 \pm 16.1$ & $11.14 \pm 2.87$ & $9.46 \pm 2.55^{*}$ \\
\hline n-3 PUFAs & $2.05 \pm 0.9$ & $8.68 \pm 1.22^{*}$ & $6.98 \pm 2.07$ \\
\hline n-6 PUFAs & $29.57 \pm 16.63$ & $3.28 \pm 2.76^{*}$ & $2.46 \pm 1.07^{*}$ \\
\hline
\end{tabular}

*significantly different compared to control $(\mathrm{P}<0.05)$. 
In post-hoc tests, the mean $\Sigma \mathrm{n} 6$ number was significantly lower in rats swimming in water at $4{ }^{\circ} \mathrm{C}$ compared to the control group and in rats swimming in water at $25^{\circ} \mathrm{C}$ compared to the control group.

\section{Discussion}

In this study erythrocyte deformability, aggregation, and fatty acid composition in erythrocyte membranes were investigated following single swimming in cold water. To our knowledge, this is the first report about the effects of swimming in cold water on erythrocyte deformability, aggregation and fatty acid composition in erythrocyte membranes.

The deformability of erythrocytes by shear force reduces the flow resistance (MAEDA 1996).

This phenomenon ameliorates blood liquidity and thus oxygen delivery to contracting muscles (EL-SAYED 1998;EL-SAYED 2005). Studies performed by CLARK (1998) revealed that older erythrocytes are less deformable under shear stress than younger ones. A small influence on erythrocyte elasticity is exerted by their internal viscosity, $\mathrm{Ca}$ and ATP binding by the membrane as well as their geometric properties such as MCV, membrane shape and fluidity (VETRUGNO et al. 2004; CARVALHO et al. 2006; KONSTANTINOVA et al. 2006). YALCIN et al. (2000) studied the immediate and latent effects of swimming in water at $32 \pm 2^{\circ} \mathrm{C}$ on the rheological properties of blood in trained and untrained rats and suggest that training can significantly limit the hemorheological alterations related to a given bout of exercise. Whether this effect is secondary to the training-induced reduction in the degree of metabolic and/or hormonal perturbation remains to be determined. In our study erythrocyte deformability indices were found to increase after swimming in water at $4^{\circ} \mathrm{C}$ at shear stress $1,13(\mathrm{~Pa})$ and 15,96 $(\mathrm{Pa})$. Perhaps an increase in erythrocyte deformability at shear stress values 1,13 and $15,96 \mathrm{~Pa}$ represents a type of protection facilitating erythrocyte flow through a constricted circulatory system due to the effort performed at low temperature and sympathetic nervous system activation.

KAYATEKIN et al. (2010) found that erythrocyte aggregation increased in swimmers after acute swimming at $26-27^{\circ} \mathrm{C}$ after 6 training sessions per week. However, YALCIN et al. (2000) found that in untrained rats erythrocyte aggregation was decreased immediately after exercise, but increased after 24 hours. In our study erythrocyte aggregation indices did not change after swimming in cold water $\left(\right.$ at $4^{\circ} \mathrm{C}$ vs. $\left.25^{\circ} \mathrm{C}\right)$. Only blood plasma viscosity increased after swimming in water at $4^{\circ} \mathrm{C}$. The results of our study confirmed that an increase in blood plasma viscosity occurs after physical effort carried out at low water temperature at $4^{\circ} \mathrm{C}$. This may adversely affect microcirculation.

PUFA acids are most numerously represented by omega-3 (n-3) and omega-6 (n-6) acids. They are present among structural lipids of erythrocyte membranes providing their proper elasticity. This enables rat erythrocytes having a diameter of ca. 5-7 $\mu \mathrm{m}$ to flow through the system of arteriovenous capillaries of diameter even less than 3-5 $\mu \mathrm{m}$. Blood flow through the capillary system is essential because it provides tissues with substrates necessary to gain energy and to fulfill their anabolic needs as well as for proper oxygenation. Catabolites and $\mathrm{CO}_{2}$ are transported out of tissues to the liver and lungs. In the microcirculation there is also a non-nutrient flow regulated by the system of precapillary sphincters built of smooth muscles that are excited by transport. In this kind of flow a pulsatory character can be discerned. Changes in the temperature in the environment must influence the dynamics of flow both in the nutritional capillary system and in the thermoregulatory system in a substantial way. Blood flow regulation depends on factors that are regulated centrally e.g. through their influence on the adrenal medulla activity and of adrenalin and noradrenalin secretion. Another important factor is local regulation operating due to the synthesis of epithelium-derived factors such as prostacyclins or eicosanoids that can change the dynamics of circulation. These compounds are derivatives of polyunsaturated fatty acids such as omega- 3 and omega- 6 .

It is known that PUFA are regulated by a system of the same enzymes belonging to a group of elongases and desaturases. However, it is not know how important is the influence of the content of particular fatty acid families, that is omega- 3 to omega- 6 for the preferability of catalysed reactions. Therefore it still remains obscure to what degree the percentage content of fatty acids changes when omega- 3 and omega- 6 acids are used up in elongation and desaturation reactions. Our results indicate a substantial decrease in body temperature of rats subjected to a single effort to exhaustion in water at both $4^{\circ} \mathrm{C}$ and $25^{\circ} \mathrm{C}$ when compared to the control group. This confirms the assumption that both physical effort and environmental factors can influence body temperature. It is known that in such circumstances changes occur in the dynamics of microcirculation and those of metabolic reactions as well as the dynamics of collateral circulation. The resulting conclusion is that in our experimental setting there was an acceleration of metabolic reactions concerning PUFA. The abrupt decrease in water at $4^{\circ} \mathrm{C}$ in omega- 6 percentage content (more than 7 times) paralleled by a ca. 4-times increasega-3 percentage content. This can be explained by a more effective use of omega- 6 acids 
for the synthesis of eicosanoids. Concomitant increase in omega- 3 acid content resulted from different range of metabolic changes of compounds belonging to this group. The present state of knowledge concerning omega- 3 and omega- 6 acids metabolism does not allow a full explanation of such substantial differences in their percentage content.

Physical effort performed in $25^{\circ} \mathrm{C}$ water resulted in an increase in saturated fatty acids and a decrease in polyunsaturated fatty acids and in polyunsaturated $n-6$ fatty acids when compared to the control group. Therefore an increase in saturated fatty acid content and decrease in polyunsaturated and polyunsaturated $n-6$ entails a stiffening of erythrocyte membrane structure. The lower the number of unsaturated bonds in polyunsaturated fatty acids PUFA and $\Sigma \mathrm{n} 6$, the more densely phospholipids are packed in cell membranes, leading to an increase in erythrocyte membrane stiffness, and eventually to disturbances in microcirculation. Thus both the fluidity and permeability of red blood cell membranes is decreased. However, in this group of rats an increase in monounsaturated fatty acid content was noted that substantially influences membrane structure and function.

In conclusion the authors plan to conduct a similar experiment with the measurements of absolute content of fatty acids in erythrocyte membranes. This will resolve the doubts concerning the reason for changes in the relative content of omega- 3 and omega- 6 fatty acids induced by physical effort.

\section{References}

Carvalho F. A., Maria A. V., Braz Nogueira J. M. Guerra J., MARTins-Silva J., SAlDANHA C. 2006. The relation between the erythrocyte nitric oxide and hemorheological parameters. Clin. Hemorheol. Microcircul. 35: 341-347.

CLARK M. R. 1988. Senescence of red blood cells: problems and progress. Physiol. Rev. 68: 503-553.

CRIBIER S., MORROT G., ZACHOWSKI A. 1993. Dynamics of the membrane lipid phase. Prostaglandins. P.L.E.F.A. 48: 27-32.

DĄBROWSKI Z. 2000. Rheological properties of blood. (In: Blood physiology, selected issues, part 2 Dabrowski Z. ed. PWN, Warsaw): 299-316. (In Polish).

DodGE J. T, PHILIPS G. B. 1967. Composition of phospholipids and of phospholipid fatty acids and aldehydes in human red cells. J. Lipid Res. 8: 667-675.

EL-SAYED M. S., Ali N., EL-SAYED Ali Z. 2005. Hemorheology in exercise and training. Sports Med. 35: 649-70.

EL-SAYED M. S.1998. Effects of exercise and training on blood rheology. Sports Med. 26: 281-92.

FOLCH J., LEES M., STANLEY G. H. S. 1957. A simple method for the isolation and purification of total lipids from animal tissue. J. Biol. Chem. 226: 497-509.
HARDEMAN M. R., DOBBE J. G. C., INCE C. 2001. The laserassisted optical rotational cell analyzer (LORCA) as red blood cell aggregometer. Clin. Hemorheol. 25:1-11.

Hardeman M. R., Goedhart P. T., DobBe J. G. C., LetTINGA K. P. 1994. Laser-assisted optical rotational cell analyser (LORCA), A new instrument for measurement of various structural hemorheological parameters. Clin. Hemorheol. 14: 605-618.

ISLAM N., CHANDA S., SEN P., Mitra Ch. 2011. Stress - mediated alteration in membrane fluidity regulates calcium ATPase activity in plasma membrane of duodenal enterocytes of oophorectomized rats. A1. Ameen. J. Med. Sci. 4: 28-37.

Kamada T., TOKuda S., AOZAKi I., OTsuj S. 1993. Higher levels of erythrocyte fluidity in sprinters and long-distance runners. J. Appl. Physiol. 74: 354-358.

Kayatekin B. M., OzCaldiran B., AKsu I., Topcu A., Ustuntas A. E., ACIK GOZ O., BEDIZ C. S. 2010. Effects of swimming on erythrocyte rheological properties. Biol. Sport. 27: 99-103.

Konstantinova E., Ivanova L., Tolstaya T., MiroNOVA E. 2006. Rheological properties of blood and parameters of platelets aggregation in arterial hypertension. Clin. Hemorheol. Microcircul. 35: 135-138.

Li Y., WATKINS B. A. 1998. Conjugated linoleic acids alter bone fatty acid composition and reduce ex vivo prostaglandin E2 biosynthesis in rats fed n-6 or n-3 fatty acids. Lipids 33: 417-425.

MAEDA N. 1996. Erythrocyte rheology and microcirculation. Jap. J. Physiol. 46: 1-14.

MCHEDlishvili G., MAEDA N. 2001. Blood flow structure related to red cell flow: A determinant of blood fluidity in narrow microvessels. Jap. J. Physiol. 51: 19-30.

MetCAlfE L. D., SCHMitz A. A. 1961. The rapid preparation of fatty acid esters for gas chromatographic analysis. Analytical Chem. 33: 363-364.

MOKKEN F. Ch., KEDARIA M., HenNy P. Ch., HARDEMAN M. R., GELB A. W. 1992 The clinical importance of erythrocyte deformability a hemorheological parameter. Ann. Hematol. 64: 113-122.

Oostenburg G. S., Mensink R. P., Hardemann M. R., VRIES D., BROUNS F., HORNSTRA G. 1997. Exercise performance, red blood cell deformability and lipid peroxidation: effects of fish oil and vitamin E. J. Appl. Physiol. 83: 746-752.

Plasenzotti R., WindBERGER U., UlBERTH F., OSTERODE W., LOSERT U. 2007. Influence of fatty acid composition in mammalian erythrocytes on cellular aggregation. Clin. Hemorheol. Microcircul. 37: 237-243.

Rodrigez M. C., SÁiz M. P., Muntané J., Mitjavila M. T. 1996. Fatty acid composition of erythrocyte membranes affects iron absorption in rats. J. Nutr. 126: 3109-3117.

ShIGA T., MAEDA N., Kon K. 1990. Erythrocyte Rheology, Critical Reviews w Oncology/Hematology 10: 9-48.

Vetrugno M., Cicco G., Cantatore F., Arnese L., DElle Noci N., SBORNIA C. 2004. Red blood cell deformability, aggregability and cytosolic calcium concentration in normal tension glaucoma. Clin. Hemorheol. Microcircul. 31: 295-302.

WEN Z., MA W., GAO T., SUN D. 1995. Effect of suspending medium viscosity on orientation and deformation of RBC in a shear field. Clin. Hemorheol. 15: 619-625.

YAlcin O., BOR-KuCUKATAY M., SENTURK U. K., BASKURT O. K. 2000. Effects of swimming exercise on red blood cell rheology in trained and untrained rats. J. Appl. Physiol. 88: 2074-2080. 